\title{
POLA KOMUNIKASI GURU KEPADA SISWA PENYANDANG DISABILITAS
}

\author{
Yani Hendrayani ${ }^{1}$, Shilvy Narulita Eka Sari ${ }^{2}$, Anjang Priliantini ${ }^{3}$ \\ Universitas Pembangunan Nasional "Veteran" Jakarta \\ Jl. RS Fatmawati, Pd. Labu, Cilandak, Jakarta Selatan, DKI Jakarta, 12450, Indonesia \\ No. Telp/HP: ${ }^{1} 089677678081,{ }^{2} 081225644625,{ }^{3} 081327175159$ \\ E-mail: ${ }^{1}$ yaniecaroline@gmail.com, ${ }^{2}$ shilvyn@ gmail.com, ${ }^{3}$ anjangpriliantini6@gmail.com
}

Naskah diterima pada tanggal 5 September 2019 direvisi tanggal 3 Oktober 2019 disetujui tanggal 18 Oktober 2019

\section{TEACHER COMMUNICATION PATTERN TO DISABILITY STUDENTS}

\begin{abstract}
Verbal and nonverbal stimuli from the environment often fail to be appropriately transferred by children with disabilities. This limitation will, of course, affect the communication patterns used by teachers and students with disabilities in building good relationships. The purpose of this study is to discuss verbal and nonverbal communication in the learning process of the art of music Degung in SLB Negeri Kota Depok. This study uses case studies with qualitative methods and uses the theory of symbolic interactionism. The results are: 1) The form of communication used for persons with disabilities is verbal and nonverbal communication. The verbal communication used by the teacher in the form of the selection of words as simple as possible; hence, students could understand verbal messages well. Nonverbal communication consists of emblems, illustrators, effect displays, regulators, and adapters; 2) Communication patterns used in the learning process of the art of music Degung utilized two communication patterns, namely interactional communication patterns and transactional communication patterns; 3) Obstacles encountered during the learning process of the art of Degung music include barriers to the delivery process, physical barriers, semantic barriers, psychological barriers, and physiological barriers.
\end{abstract}

Keywords: communication patterns, students with disabilities, Degung art music.

Abstrak. Seringkali stimulus verbal dan nonverbal dari lingkungan gagal ditransfer dengan baik oleh anak penyandang disabilitas. Keterbatasan ini tentu saja akan berpengaruh pada pola komunikasi yang digunakan oleh guru dan murid penyandang disabilitas dalam membangun hubungan yang baik. Tujuan penelitian ini adalah untuk membahas komunikasi verbal dan nonverbal dalam proses pembelajaran seni musik Degung di SLB Negeri Kota Depok. Penelitian ini menggunakan studi kasus dengan metode kualitatif serta menggunakan teori interaksionisme simbolik. Adapun hasil dalam penelitian ini adalah: 1) Bentuk komunikasi yang digunakan untuk penyandang disabilitas adalah komunikasi verbal dan nonverbal. Penggunaan komunikasi verbal oleh guru berupa pemilihan kata yang sesederhana mungkin, sehingga pesan verbal dapat dipahami secara baik oleh siswa. Komunikasi nonverbal terdiri dari emblem, illustrator, effect display, regulator, dan adaptor; 2) Pola komunikasi yang digunakan dalam proses pembelajaran seni musik Degung menggunakan dua pola komunikasi yaitu pola komunikasi interaksional dan pola komunikasi transaksional; 3) Hambatan yang dihadapi saat proses pembelajaran seni musik Degung ini meliputi hambatan proses penyampaian, hambatan fisik, hambatan semantik, hambatan psikologis, dan hambatan fisiologis.

Kata kunci: pola komunikasi, siswa penyandang disabilitas, seni musik Degung. 


\section{PENDAHULUAN}

Terdapat 1,6 juta anak penyandang disabilitas dan lebih dari separuhnya belum mendapatkan layanan pendidikan di Indonesia saat ini (Maulipaksi, 2017). Menurut Effendi (2009), anak penyandang disabilitas yang cenderung lebih sulit dalam memahami pelajaran adalah anak tunarungu dan tunagrahita. Tunarungu memiliki keterbatasan sulit mendengar dan sulit dalam berbicara, sedangkan tunagrahita memiliki keterbelakangan mental dan fisik sejak masih dalam kandungan. Seringkali stimulus verbal dan nonverbal dari lingkungan gagal ditransfer dengan baik. Bahkan hal-hal yang sederhana sekalipun terkadang sulit dicerna dengan baik. Padahal dalam proses belajarmengajar guru dalam menyampaikan informasi menggunakan komunikasi secara verbal dan nonverbal. Keterbatasan ini tentu saja akan memengaruhi pencapaian tujuan komunikasi dalam pembelajaran.

Dalam proses kegiatan belajar mengajar, perlu adanya komunikasi guru dan siswa dengan tatap muka, baik secara verbal maupun nonverbal dan secara individual maupun secara kelompok. Komunikasi antara guru dan siswa dapat membangun hubungan yang baik dan dapat membantu proses belajar mengajar sehingga membentuk suatu pola komunikasi. Pola komunikasi dapat digunakan untuk mengembangkan interaksi antara guru dan siswa. Pola komunikasi sangat diperlukan oleh seorang guru dalam membangun komunikasi serta interaksi yang baik dengan siswa dalam proses belajar.

Menteri Pendidikan dan Kebudayaan Republik Indonesia, Muhadjir Effendy, mengungkapkan bahwa setiap sekolah harus mampu mengembangkan minat dan bakat siswa penyandang disabilitas, agar tidak tertinggal oleh siswa yang normal. Anak penyandang disabilitas harus dibantu untuk menggali minat dan bakat dengan lebih mendalam karena anak-anak penyandang disabilitas diidentikkan dengan anak-anak yang tidak memiliki kemampuan (Baqiroh, 2018). Lebih lanjut, Muhadjir Effendy juga mengatakan bahwa selain tidak memiliki kemampuan, anak-anak disabilitas didiskriminasi di lingkungan sehingga perlu mendapatkan pengembangan minat dan bakat yang kemudian dipupuk secara terus-menerus sehingga mereka bisa menjadi manusia yang utuh secara hakikat, memiliki kepercayaan diri, kemandirian, dan tentu saja bisa meraih penghargaan yang layak sesuai prestasi yang diraih (Mudjito, 2013).

Sekolah Luar Biasa (SLB) merupakan lembaga pendidikan yang bertujuan untuk membantu anak penyandang disabilitas dalam memberikan pendidikan sebagaimana layaknya anak-anak normal pada umumnya. Selain berfungsi sebagai lembaga pendidikan umum, SLB juga berperan sebagai wadah untuk mengembangkan siswa-siswi yang berkebutuhan khusus dalam meningkatkan minat dan bakat, kepercayaan diri, kreativitas, dan kemandirian untuk masa depannya (UU Sisdiknas Tahun 2003 Pasal 1 Ayat 1).

Menurut Ali (2007), bukan hanya ilmu pengetahuan di bidang eksakta maupun sosial saja yang dibutuhkan oleh siswa. Siswa juga perlu dibekali keterampilan untuk mengembangkan minat dan bakat, kepercayaan diri, kreativitas, dan kemandirian untuk masa depannya di luar pelajaran umum melalui pendidikan kesenian. Melalui kesenian, anak penyandang disabilitas dapat mengembangkan minat dan bakatnya sehingga mereka memiliki kepercayaan diri dan tentu dapat berprestasi sesuai dengan bidang yang ditekuninya.

Seni musik menurut Uttara Sharma, psikolog anak di Bangalore, India dapat menurunkan perilaku sulit konsentrasi, mendorong bekerjasama, serta memiliki keterampilan motorik halus dan kasar (Putri, 2015). Keuntungan mempelajari seni musik ini juga sejalan dengan amanat Kurikulum Tingkat Satuan Pendidikan (KTSP) bahwa pendidikan bagi siswa pada dasarnya juga memuat standar kompetensi yang mencakup: (1) Apresiasi musik daerah setempat; (2) Apresiasi musik daerah nusantara; dan (3) Pergelaran musik. Dengan demikian, dapat disimpulkan bahwa seni musik sangat penting diterapkan dalam pembelajaran di sekolah, terutama diterapkan kepada anak penyandang disabilitas sehingga anak penyandang disabilitas tersebut bisa lebih berkonsentrasi, mendorong bekerjasama, dan memiliki keterampilan motorik halus dan kasar dan 
tentu saja bisa menghasilkan prestasi dalam bidang musik. Dengan demikian, keterbatasan fisik tidak menjadi halangan untuk dapat berprestasi dalam bidang kesenian terutama dalam seni musik. Berdasarkan hal tersebut, peneliti memilih seni musik untuk diteliti.

Sekolah negeri maupun swasta memiliki karakteristik mereka sendiri. Sehingga dengan karakteristik masing-masing akan menampilkan perbedaan antara yang satu dengan yang lain. Berdasarkan data yang diperoleh dari hasil wawancara prapenelitian dengan Kepala Sekolah SLB Negeri Kota Depok, SLB Negeri menggunakan Kurikulum Tingkat Satuan Pendidikan (KTSP atau Kurikulum 2013) yang distandardisasi oleh Depdiknas. Secara proporsional, kurikulum pada SLB Negeri menitikberatkan pada program keterampilan. Selain itu, amanat Kurikulum 2013 juga menegaskan bahwa sekolah harus menerapkan pendidikan karakter. Pendidikan karakter tersebut dapat diberikan melalui pendidikan nonakademis, yaitu melalui kesenian.

Objek dalam penelitian ini adalah Sekolah Luar Biasa Negeri Kota Depok, sebab SLB ini merupakan satu-satunya SLB berstatus sekolah negeri dan terakreditasi A, serta memiliki kesenian musik Degung yang menjadi seni musik khas Sunda, Jawa Barat sebagai salah satu pokok pelajaran.

Sejak dikeluarkannya Peraturan Menteri Pendidikan dan Kebudayaan Republik Indonesia Nomor 81A Tahun 2013 tentang Implementasi Kurikulum 2013 disepakati bahwa setiap sekolah wajib mengadakan pembelajaran seni musik daerah. Oleh karena itu SLB Negeri Kota Depok mengadakan seni musik daerah yaitu seni musik Degung karena letak sekolah ini berada di wilayah Jawa Barat. Sekolah tersebut juga turut andil dalam melestarikan kesenian musik Degung, serta bertujuan untuk menggali minat dan bakat, kepercayaan diri, kreativitas, dan tentu saja agar dapat meraih penghargaan melalui kesenian musik Degung. Kesenian musik Degung di sekolah ini telah menghasilkan prestasi yaitu dengan memenangkan juara 1 lomba musik Degung wilayah Depok dengan mengalahkan 10 sekolah SLB di Depok pada tahun 2016.
Peneliti menemukan hal menarik pada saat prapenelitian, yaitu ketika penyelenggaraan pembelajaran kesenian musik Degung di SLB Negeri Kota Depok. Dalam prapenelitian tersebut, diketahui bahwa pendidik pembelajaran kesenian musik Degung juga merupakan penyandang tunanetra. Dengan keterbatasan tersebut tentu pendidik memiliki cara khusus untuk dapat berkomunikasi dan menyelenggarakan kegiatan belajar mengajar pada siswa-siswi yang juga merupakan penyandang disabilitas tunarungu dan tunagrahita.

Berdasarkan penjabaran permasalahan di atas, penulis bermaksud untuk meneliti bagaimana pola komunikasi guru kepada siswa disabilitas dalam mengajar seni musik Degung di SLB Negeri Kota Depok. Karena dalam proses belajar mengajar di SLB Negeri Kota Depok, pendidik mempunyai keterbatasan yaitu penyandang tunanetra dan siswa-siswi memiliki keterbatasan yaitu tunarungu dan tunagrahita, dimana stimulus verbal dan nonverbal dari lingkungan gagal ditransfer dengan baik dan dibutuhkan pola komunikasi yang baik antara pendidik dengan para siswa dan siswi.

\section{LANDASAN KONSEP}

\section{Pola Komunikasi}

Komunikasi adalah suatu proses penyampaian informasi (pesan, ide, gagasan) dari satu pihak kepada pihak lain. Pada umumnya, komunikasi dilakukan secara lisan atau verbal yang dapat dimengerti oleh kedua belah pihak. Apabila tidak ada bahasa verbal yang dapat dimengerti oleh keduanya, komunikasi masih dapat dilakukan dengan menggunakan gerak-gerik badan, menunjukkan sikap tertentu, misalnya tersenyum, menggelengkan kepala, mengangkat bahu. Cara seperti ini disebut komunikasi nonverbal (Fiske, 2012).

Dengan mengadakan komunikasi, setiap manusia dapat menyampaikan dan mengungkapkan apa yang mereka rasakan, yang diinginkan, dan yang diharapkan. Begitu pula halnya dengan komunikasi antara guru dan murid, di mana guru sebagai penyampai 
informasi dan murid sebagai penerima informasi yang diberikan guru.

Pola komunikasi diartikan sebagai pola hubungan dua orang atau lebih dalam proses pengiriman dan penerimaan cara yang tepat sehingga pesan yang dimaksud dapat dipahami Djamarah dalam Kusnarto dan Saifudin Z (2010). Pola komunikasi merupakan model dari proses komunikasi, sehingga dengan adanya berbagai macam model komunikasi dan bagian dari proses komunikasi akan dapat ditemukan pola yang cocok dan mudah digunakan dalam berkomunikasi. Di dalam pola komunikasi terdapat proses komunikasi. Proses komunikasi adalah bagaimana komunikator menyampaikan pesan kepada komunikannya, sehingga dapat menciptakan suatu persamaan makna antara komunikator dengan komunikan. Proses komunikasi ini bertujuan untuk menciptakan komunikasi yang efektif.

Menurut Effendy (2011), proses yang terjadi dalam komunikasi secara umum ada dua, yaitu proses komunikasi primer (primary process) dan proses secara sekunder (secondary process). Uraiannya sebagai berikut:

Proses Komunikasi Primer (Primary Process). Pola komunikasi primer merupakan suatu proses penyampaian oleh komunikator kepada komunikan dengan menggunakan suatu simbol sebagai media atau saluran. Dalam pola ini terbagi menjadi dua lambang, yaitu verbal dan nonverbal.

Proses secara Sekunder (Secondary Process). Pola komunikasi secara sekunder adalah proses penyampaian oleh komunikator kepada komunikan dengan menggunakan alat atau sarana sebagai media kedua setelah memakai lambang pada media pertama.

Dari proses komunikasi akan timbul pola, model, dan juga bagian-bagian kecil yang berkaitan erat dengan proses komunikasi. Sedangkan pola komunikasi juga terbagi menjadi dua bagian, istilah pola komunikasi bisa disebut juga sebagai model komunikasi. Tetapi maksudnya sama, yaitu sistem yang terdiri atas berbagai komponen yang berhubungan antara yang satu dengan yang lainnya.

Pola atau model komunikasi menurut (West \& Turner, 2008; Majid, 2013): 1) Pola
Komunikasi Interaksional (Interactional Model of Communication). Komunikasi ini lebih menekankan pada proses komunikasi dua arah dari pengirim pesan kepada penerima dan dari penerima kepada pengirim pesan. Elemen yang paling penting dalam komunikasi ini adalah adanya umpan balik atau tanggapan terhadap suatu pesan. Umpan balik dapat berupa verbal maupun nonverbal, sengaja maupun tidak sengaja. Umpan balik sangat membantu komunikator untuk mengetahui apakah pesan mereka telah tersampaikan atau tidak dan sejauh mana pencapaian makna terjadi setelah pesan diterima. Pada komunikasi ini guru dan siswa dapat berperan sama yaitu pemberi aksi dan penerima aksi. Hal ini menunjukkan bahwa telah terjadi hubungan dua arah, tetapi terbatas pada guru dan siswa secara individual sedangkan antara pelajar satu dengan pelajar lainnya tidak ada hubungan. Peserta didiknya tidak dapat berinteraksi dengan teman lainnya. Komunikasi ini lebih baik dari yang pertama; 2) Pola Komunikasi Transaksional (Transactional Model of Communication). Konseptualisasi komunikasi sebagai transaksi ini lebih bersifat dinamis, konsep ini juga berpandangan bahwa orangorang yang berkomunikasi adalah komunikator-komunikator yang aktif mengirimkan pesan dan menafsirkan pesan. Setiap pihak dianggap sumber sekaligus juga penerima pesan. Setiap saat mereka bertukar pesan verbal dan nonverbal. Pendekatan komunikasi transaksional menyarankan bahwa semua unsur dalam proses komunikasi saling berhubungan.

Dalam konsep ini, komunikasi dikatakan berjalan jika seseorang telah menafsirkan perilaku orang lain, baik perilaku verbal maupun perilaku nonverbalnya. Pemahaman ini mirip dengan konsep "receiver-oriented definition" atau definisi berorientasi penerima yang menekankan variabel-variabel yang berbeda yakni penerima dan makna pesan bagi penerima, hanya saja penerimaan pesan itu juga berlangsung dua arah atau banyak arah. Dalam proses komunikasi transaksional semuanya berlangsung secara simultan dan spontan. Termasuk di dalamnya adalah ketika seorang guru menyampaikan pembelajaran, 
ada peserta didik yang justru fokus pada cara guru berbicara seperti gaya dan pilihan kata guru tersebut yang menarik. Sehingga dalam konteks ini, peserta didik tidak hanya memberikan respon terhadap pelajaran yang disampaikan namun juga peserta didik secara tidak langsung memberikan respon positif terhadap gaya berbicara gurunya.

\section{Komunikasi Verbal dan Nonverbal}

Komunikasi verbal adalah komunikasi yang menggunakan kata-kata, baik lisan maupun tulisan sehingga bahasa memegang peranan penting dalam proses komunikasi ini (Kusumawati, 2016). Komunikasi nonverbal adalah komunikasi yang menggunakan bahasa isyarat dan bukan kata-kata (Mulyana, 2010). Menurut Larry A. Samovar dan Richard E. Porter dalam Mulyana (2012), komunikasi nonverbal mencakup semua rangsangan (kecuali rangsangan verbal) dalam suatu setting komunikasi, yang dihasilkan oleh individu dan memiliki nilai pesan potensial bagi pengirim atau penerima. Sehingga komunikasi nonverbal mencakup perilaku yang disengaja maupun tidak disengaja sebagai bagian dari peristiwa komunikasi secara keseluruhan di mana pesan yang disampaikan tersebut bermakna bagi orang lain (Nurmala, Rina, Syarif Maulana, 2016).

Mengomunikasikan pikiran dan perasaan seringkali lebih akurat melalui gerakan tubuh, gerakan wajah, dan gerakan mata (DeVito, 2011). Menurut Ekman Paul dan Wallace V. Friesen (1969) dalam (Devito, 2011), terdapat lima kelompok gerakan nonverbal atau gerakan tubuh berdasarkan asal-usul, fungsi, dan kode perilaku:

- Emblem, teknik emblem adalah perilaku nonverbal yang secara langsung menerjemahkan kata atau ungkapan.

- Illustrator adalah perilaku nonverbal yang menyertai dan secara harfiah "mengilustrasikan" pesan verbal.

- Regulator adalah perilaku nonverbal mengatur, memantau, memelihara, atau mengendalikan pembicaraan orang lain.

- Gerakan wajah (effect display) adalah isyarat yang terjadi karena adanya dorongan emosional sehingga berpengaruh terhadap ekspresi muka.

- Adaptor adalah perilaku nonverbal yang bila dilakukan secara pribadi atau di muka umum tetapi tidak terlihat.

\section{Hambatan Komunikasi}

Hambatan komunikasi terjadi karena gangguan yang membuat proses komunikasi tidak dapat berlangsung sesuai harapan komunikator dan komunikan. Hambatan objektif adalah gangguan atau halangan terhadap jalannya komunikasi yang tidak sengaja dibuat oleh pihak lain, tapi mungkin juga disebabkan oleh keadaan yang tidak menguntungkan.

Hambatan-hambatan dalam komunikasi menurut DeVito (2007) dalam Hijrah (2017) yaitu: hambatan fisik (physical barriers), hambatan yang datang dari lingkungan. Hambatan semantik (semantic barriers), hambatan segi semantik (bahasa dan arti perkataan) yaitu adanya perbedaan pengertian dan pemahaman antara pemberi pesan dan penerima tentang satu bahasa atau lambanglambang. Hambatan psikologis (psychological barriers), hambatan yang disebabkan oleh faktor kejiwaan seseorang. Hambatan fisiologis (physiological barriers), hambatan yang berkaitan dengan kondisi tubuh yang tidak sedang berada pada kemampuan terbaiknya.

\section{Definisi Tunarungu dan Tunagrahita}

Wasito, Dian Rachmawati, Dwi Sarwindah (2010) mengemukakan bahwa tunarungu adalah kurangnya atau hilangnya kemampuan mendengar dan diklasifikasikan ke dalam kategori ringan sampai berat.

Tunagrahita menurut Kustawan (2016) merupakan anak yang memiliki inteligensi yang signifikan berada di bawah rata-rata dan disertai dengan ketidakmampuan dalam adaptasi perilaku yang muncul dalam masa perkembangan. Kustawan dalam Sari, Siti Fatimah Mutia, Binahayati (2017) juga mengatakan bahwa anak dengan tunagrahita mempunyai hambatan akademik yang sedemikian rupa sehingga dalam layanan pembelajarannya memerlukan modifikasi kurikulum yang sesuai dengan kebutuhan khususnya. 


\section{Kesenian Musik Degung}

Degung adalah gamelan khas tradisional Sunda. Di Provinsi Jawa Barat, seluruh sekolah dasar mempelajari kesenian musik Degung (Julia, Supriyadi, Tedi, 2018). Resna, R.W., Yusniarsih, I., dan Yuliani (2017) dalam penelitiannya menemukan bahwa seni musik Degung merupakan musik terapi.

\section{Teori Interaksionisme Simbolik}

Penggunaan teori interaksionisme simbolik dalam penelitian ini dilandasi karena kerangka pemikiran dalam teori tersebut memiliki tendensi-tendensi yang kuat guna menganalisis penelitian ini. Fokus teori interaksionisme simbolik terletak pada proses penafsiran dan memahami simbol-simbol agar aktor bisa saling menyesuaikan tindakan mereka. Menurut asumsi karya Herbert Blumer (1969) dalam West \& Turner (2008), ide dasar dari teori interaksionisme simbolik adalah: (a) Manusia bertindak atau bersikap terhadap orang lain dilandasi atas pemaknaan kepada orang lain; (b) Pemaknaan muncul dari interaksi sosial yang dipertukarkan di antara manusia; (c) Interaksionisme simbolik menggambarkan proses berpikir sebagai perbincangan dengan diri sendiri. Dengan demikian, teori interaksi simbolik dapat didefinisikan sebagai cara manusia yang senantiasa menciptakan makna dan memanipulasi simbol-simbol pada saat berinteraksi. Fokus dari pendekatan teori interaksi simbolik yaitu pada cara manusia dalam berinterakasi melalui simbol-simbol yang dapat berupa kata, gerak tubuh, nilai, norma, dan peran. Untuk itu, komunikasi yang terjalin secara pribadi bukan karena didasarkan pada tindakan pribadinya, melainkan karena keanggotaan dirinya dalam kelompok masyarakat. Makna dapat ada hanya ketika orang-orang memiliki interpretasi yang sama mengenai simbol yang mereka pertukarkan dalam interaksi.

\section{METODE PENELITIAN}

Penelitian ini menggunakan metode penelitian kualitatif. Pertimbangan penulis dalam memilih metode penelitian kualitatif adalah karena penelitian ini merupakan riset yang bersifat deskriptif dan cenderung menggunakan analisis. Peneliti menggunakan metode penelitian kualitatif karena ingin menggali informasi lebih dalam mengenai bagaimana pola komunikasi guru kepada siswa penyandang disabilitas, terutama pada proses pengajaran seni musik Degung di SLB Negeri Kota Depok.

Proses dan makna lebih diperlihatkan dalam penelitian kualitatif dan peneliti menggunakan metode studi kasus. Salah satu ciri penelitian studi kasus adalah adanya keunikan dalam objek penelitian. Dalam penelitian ini, keunikan ditunjukkan dari adanya fenomena proses belajar mengajar pada siswa penyandang disabilitas di SLB Negeri Kota Depok dilakukan oleh guru yang juga menyandang disabilitas, yaitu tunanetra.

Dalam penelitian ini, peneliti menggunakan informan utama (key informant) yaitu guru musik Degung serta pendukung informan utama (informant) yaitu guru tunarungu dan tunagrahita, siswa tunarungu dan tunagrahita dan orang tua siswa tunarungu dan tunagrahita. Data primer dilakukan dengan wawancara mendalam (indepth interview) dan observasi dengan cara terjun langsung ke lapangan. Data sekunder, berupa data dan informasi dari dokumentasi, sumber buku, dan jurnal. Menurut Miles dan Huberman dalam Sugiyono (2016), kegiatan analisis terdiri dari tiga alur kegiatan, yaitu reduksi data atau kodifikasi data, penyajian data, dan penarikan kesimpulan atau verifikasi. Validitas data yang digunakan adalah triangulasi sumber yang berarti membandingkan ulang derajat kepercayaan suatu informasi yang diperoleh melalui sumber yang berbeda (Sugiyono, 2016).

\section{HASIL PENELITIAN DAN PEMBAHASAN}

Fokus penelitian ini adalah pola komunikasi yang dilakukan guru kepada siswa penyandang disabilitas dalam proses pengajaran seni musik Degung di SLB Negeri Kota Depok. Siswa penyandang disabilitas yang menjadi fokus dalam penelitian ini adalah murid tunarungu dan tunagrahita. 
Perlu diketahui, kekurangan murid tunarungu terletak pada ketidakmampuannya dalam mendengar dan berbicara, sedangkan kekurangan murid tunagrahita terletak pada lemahnya mental dalam mendengar dan berbicara.

Terdapat beberapa temuan dalam proses pengajaran seni musik Degung kepada siswa penyandang disabilitas di SLB Negeri Kota Depok dalam penelitian ini. Instruksi yang disampaikan kepada siswa tunarungu dan tunagrahita harus lebih disederhanakan. Bobot materi pelajaran disesuaikan dengan kemampuan dan kesanggupan murid itu sendiri. Hal tersebut dikarenakan siswa berkebutuhan khusus memiliki karakteristik inteligensi yang berbeda sehingga berpengaruh pada daya tangkap materi pembelajaran.

Peneliti terjun langsung untuk melihat proses kegiatan belajar mengajar serta melihat pola komunikasi yang terjadi dalam pembelajaran seni musik Degung di SLB Negeri Kota Depok antara guru kepada muridnya. Keterbatasan yang dimiliki oleh anak tunarungu dan tunagrahita mendasari terbentuknya suatu pola komunikasi yang dijalin oleh guru kepada siswa sehingga penyampaian materi lebih efektif dan mudah dipahami. Pola komunikasi juga dapat digunakan untuk mengembangkan interaksi antara guru dan siswa sehingga dapat membantu proses belajar mengajar.

Guru dapat menambahkan keakraban secara bertahap dalam proses berkomunikasi dengan Anak Berkebutuhan Khusus (ABK). Pertama, membuat kontak awal yang melibatkan persepsi alat indera seperti melihat dan mendengar. Setelah tahap kontak awal, guru harus menempatkan diri mereka sebagai teman agar siswa meresa nyaman dengan guru. Pembawaan diri yang bersahabat, penuh dengan keceriaan, dan positif. Kemudian, tahap kedua adalah tahap keakraban. Tahap keakraban memerlukan interaksi yang lebih jauh untuk meningkatkan diri dalam tahap untuk membina hubungan yang lebih dalam.

Guru dalam berkomunikasi dengan siswa ABK memerlukan komunikasi secara verbal dan nonverbal untuk menekankan makna agar siswa sebagai komunikan mengerti apa yang disampaikan berupa pesan (materi) oleh komunikator, yaitu guru. Hal ini sesuai dengan teori yang peneliti gunakan, yaitu teori interaksionisme simbolik. Teori interaksionisme simbolik dapat didefinisikan sebagai cara manusia yang senantiasa menciptakan makna dan memanipulasi simbol-simbol pada saat berinteraksi. Fokus dari pendekatan teori interaksi simbolik yaitu pada cara manusia dalam berinterakasi melalui simbol-simbol yang dapat berupa kata, gerak tubuh, nilai, norma, dan peran. Untuk itu, komunikasi yang terjalin secara pribadi bukan karena didasarkan pada tindakan pribadinya, melainkan karena keanggotaan dirinya dalam kelompok masyarakat. Makna dapat ada hanya ketika orang-orang memiliki interpretasi yang sama mengenai simbol yang mereka pertukarkan dalam interaksi.

\section{Komunikasi Verbal dan Nonverbal Guru kepada Siswa Penyandang Disabilitas dalam Mengajar Seni Musik Degung di SLB Negeri Kota Depok}

Di dalam suatu pola komunikasi, terdapat proses komunikasi yang terdiri dari proses komunikasi secara verbal maupun nonverbal. Komunikasi verbal menekankan keberadaan interaksi bahasa sebagai alat utama guru dalam melakukan komunikasi dengan murid. Bahasa dapat digambarkan sebagai kode dan simbol yang digunakan untuk membentuk pesan-pesan verbal. Simbol atau pesan verbal adalah semua jenis simbol yang menggunakan satu kata atau lebih. Menurut Mulyana (2005) dan Kusumawati (2016) bahasa dapat juga dianggap sebagai sistem kode verbal. Bahasa dapat didefinisikan sebagai seperangkat simbol dengan aturan untuk mengombinasikan simbol-simbol tersebut yang digunakan dan dipahami oleh suatu komunitas.

Komunikasi verbal secara umum digunakan oleh banyak orang, termasuk oleh guru di SLB Negeri Kota Depok. Dengan menggunakan komunikasi secara verbal dalam proses pembelajaran seni musik Degung, guru dapat memberikan pemahaman dan pengarahan baik sebelum dan sesudah kegiatan belajar mengajar berlangsung. 
Dalam proses pembelajaran, bentuk komunikasi yang digunakan berupa komunikasi verbal dan komunikasi nonverbal. Komunikasi verbal menekankan keberadaan interaksi bahasa sebagai alat utama guru dalam melakukan komunikasi dengan murid. Bahasa yang digunakan cenderung sederhana sehingga mudah dipahami oleh anak tunarungu maupun tunagrahita. Komunikasi antara guru dengan siswa tunarungu di SLB Negeri Kota Depok menggunakan bahasa verbal, namun hal ini perlu ditegaskan dan dibantu dengan bahasa nonverbal atau bahasa isyarat. Oleh karena itu, komunikasi verbal dan nonverbal sangat berperan dalam proses komunikasi guru ketika mengajar anak tunarungu. Karena pada dasarnya siswa tunarungu mampu mengeja dengan gerakan bibir.

Murid tunarungu kesulitan dalam mendengar bunyi-bunyian dan memproses informasi saat belajar seni musik degung. Kesulitan dalam mendengar bunyi-bunyian dan memproses informasi. Oleh karena itu guru lebih banyak menggunakan komunikasi dalam bentuk nonverbal dengan menggunakan bahasa isyarat agar komunikasi yang terjalin antara guru dengan murid berjalan dengan efektif dan pesan yang disampaikan guru seni musik Degung dapat diterima oleh siswa tunarungu. Komunikasi nonverbal menekankan aspek komunikasi pada setiap gerakan tubuh, gerakan mata, ekspresi wajah, penggunaan jarak, kecepatan dan volume bicara, bahkan juga keheningan.

Guru menggunakan Simbol Isyarat Bahasa Indonesia (SIBI) sebagai bentuk komunikasi dasar nonverbal, seperti huruf abjad atau angka. Menurut DeVito dalam Lestari, Maya Puji, Naryoso, Agus (2013), ada lima bentuk komunikasi nonverbal yang dilakukan guru di SLB Negeri Kota Depok ketika memberikan instruksi dengan gerakan tubuh, yaitu emblem, illustrator, regulator, gerakan wajah (effect display), dan adaptor.

Emblem adalah perilaku nonverbal yang secara langsung menerjemahkan kata-kata atau ungkapan. Emblem meliputi misalnya isyarat "baik", "oke", "bagus", dan "kurang". Emblem adalah komunikasi nonverbal untuk mengganti kata-kata atau ungkapan tertentu. Dengan menggunakan teknik emblem, guru seni musik Degung di SLB Negeri Kota Depok sering mengungkapkan kata-kata "jelek" dan "baik" atau "bagus" dengan menggunakan bahasa isyarat. Guru menggunakan teknik emblem untuk menjelaskan alunan musik atau harmoninya sudah baik atau jelek kepada tunarungu dan tunagrahita. Khusus untuk murid penyandang tunagrahita, guru berbicara seperti biasa dengan mengatur intonasi suaranya. Misalnya jika memainkan alat musiknya bagus atau waditra intonasi dalam berbicara "bagus" dinaikkan dan lantang kemudian ditekankan dengan isyarat jari jempol ke atas.

Penggunaan isyarat jari jempol ke atas dan ke bawah dipahami oleh murid penyandang tunarungu dan tunagrahita sebagai ungkapan kata baik dan jelek. Isyarat ini sangat umum dan mudah diterima oleh murid penyandang tunagrahita maupun tunarungu meski keduanya memiliki karakteristik dan kemampuan yang berbeda. Saat guru mengacungkan jari jempol ke atas, maka murid mengetahui bahwa alunan musik Degung yang dibawakan oleh mereka telah selaras dan perlu dipertahankan hingga akhir sesi latihan. Sebaliknya, ketika murid melihat guru mengacungkan jari jempol ke bawah, maka pesan yang dimaknai oleh murid adalah adanya kesalahan atau ketidakselarasan dalam memainkan musik Degung. Karenanya, murid-murid kemudian mengecek kembali buku panduan di depannya, menengok ke teman yang ada di kanan dan kirinya, mengernyitkan dahi, menghentikan sejenak alunan musik yang dimainkan, atau bahkan berhenti berlatih.

Illustrator adalah perilaku nonverbal yang menyertai dan secara harfiah "mengilustrasikan" pesan verbal. Dalam mengatakan "bersama-sama", misalnya. Illustrator bersifat lebih alamiah, kurang bebas, dan lebih universal daripada teknik emblem. Illustrator merupakan tanda-tanda nonverbal dalam komunikasi. Tanda ini merupakan gerakan anggota tubuh yang menjelaskan atau menunjukkan suatu contoh. Guru di SLB Negeri Kota Depok menggunakan teknik illustrator untuk menjelaskan kegiatan seni musik Degung yang harus dikerjakan secara bersamaan dan 
menggambarkan nada tinggi atau rendah dengan simbol tertentu.

Berbeda dengan emblem yang merupakan isyarat yang bertujuan untuk menggambarkan keadaan yang baik (jempol ke atas) dan jelek (jempol ke bawah), maka teknik ilustrasi digunakan oleh guru SLB Negeri Kota Depok untuk memberikan instruksi melalui gerakan nonverbal. Musik Degung adalah seni musik yang harus dikerjakan berkelompok karena merupakan gabungan alunan dari beberapa alat musik. Karenanya, guru menggunakan kedua tangannya dan membentuk lingkaran di depan dada yang artinya meminta seluruh murid berkelompok, bekerjasama, dan kompak dalam memainkan seni musik Degung.

Selain menggunakan kedua tangan untuk meminta murid-murid berkelompok dan bekerjasama, guru juga menggunakan tangan untuk menginstruksikan murid dalam mengambil nada tinggi maupun rendah. Teknik ini lazim digunakan karena dianggap mampu diterima oleh murid tunarungu dan tunagrahita yang memiliki perbedaan karakteristik. Guru meminta murid-murid untuk berkonsentrasi dengan memperhatikan gerakan tangan guru. Saat tangan guru diayun ke atas, artinya murid harus memainkan nada tinggi dengan ritme nada yang cepat, begitu juga sebaliknya saat tangan guru diayun ke bawah, artinya murid harus memainkan nada rendah dan ritme nada yang pelan.

Regulator adalah perilaku nonverbal yang mengatur, memantau, memelihara, atau mengendalikan pembicaraan orang lain. Regulator mengisyaratkan kepada pembicara apa yang diharapkan untuk mereka lakukan. Mereka mengubah perilaku sesuai dengan pengarahan regulator berdasarkan kepekaannya. Guru di SLB Negeri Kota Depok saat melatih seni musik Degung menggunakan teknik regulator dengan isyarat "teruskanlah", "coba tolong dilambatkan", "agak cepat sedikit ya", "ayo dipukulnya pakai tenaga", "pelan-pelan" dan "ayo konsentrasi, lihat ke depan" dan "jangan ngobrol".

Effect display adalah gerakan-gerakan wajah yang mengandung makna emosional, gerakan ini memperlihatkan rasa marah, takut, gembira, sedih, semangat, dan kelelahan. Guru menggunakan teknik effect display untuk mengekspresikan saat melihat kegiatan siswa berlatih Degung, misalnya ketika siswa salah memukulnya tidak sesuai dengan notasi yang sudah diajarkan guru akan mengeluarkan ekspresi marah ataupun ekspresi yang menunjukkan bahwa mereka salah dengan notasinya. Sedangkan apabila latihannya berhasil guru akan mengekspresikan dengan wajah gembira.

Penggunaan gerakan wajah seperti ekspresi atau mimik mampu diterima oleh murid tunarungu dan tunagrahita sebagai respon guru terhadap hasil latihan muridmurid. Gerakan wajah yang ditampilkan guru memiliki perbedaan makna sesuai dengan ekspresi yang ditunjukkan. Gerakan wajah juga merupakan teknik yang umum digunakan karena dianggap mampu diterima oleh murid penyandang tunarungu maupun tunagrahita. Ketika guru menampilkan gerakan wajah yang gembira atau senang, maka murid akan mempertahankan keselarasan dan konsentrasi mereka dalam berlatih. Sebaliknya saat guru menunjukkan ekspresi wajah marah, maka murid akan merasa bingung dan mencari tahu letak kesalahannya sendiri.

Adaptor adalah perilaku nonverbal yang bila dilakukan secara pribadi atau di muka umum tetapi tidak terlihat, berfungsi memenuhi kebutuhan tertentu dan dilakukan sampai selesai. Dalam hal ini guru di SLB Negeri Kota Depok memberikan perhatian dalam bentuk menyemangati. Contohnya menepuk pundak siswa atau mengelus pundak dan rambut siswa yang menandakan bahwa penyemangatan dan motivasi kepada siswa. Penyemangatan dilakukan agar siswa memiliki keinginan belajar terus-menerus.

Teknik adaptor dengan menggunakan sentuhan atau kontak fisik pada murid juga lazim digunakan karena dianggap mampu diterima oleh murid penyandang tunarungu dan tunagrahita. Murid penyandang disabilitas ini pada dasarnya selalu mencari perhatian orang lain, karenanya ketika guru menepuk atau mengelus pundak mereka artikan sebagai bentuk perhatian guru sekaligus apresiasi terhadap hasil latihan. 


\section{Pola Komunikasi Guru kepada Siswa Penyandang Disabilitas dalam Proses Pembelajaran Seni Musik Degung di SLB Negeri Kota Depok}

Berdasarkan hasil observasi dan wawancara yang dilakukan oleh peneliti terhadap beberapa informan kunci dan informan, pelaksanaan pola komunikasi yang dilakukan oleh guru kepada siswa tunarungu dan tunagrahita dalam proses pembelajaran seni musik Degung di SLB Negeri Kota Depok menggunakan dua pola komunikasi. Pola komunikasi yang digunakan tersebut adalah pola komunikasi interaksional (interactional model of communication) dan pola komunikasi transaksional (transactional model of communication). Kedua pola komunikasi tersebut diuraikan sebagai berikut: (1) Pola komunikasi interaksional (interactional model of communication). Komunikasi ini lebih menekankan pada proses komunikasi dua arah, dari pengirim pesan kepada penerima dan dari penerima kepada pengirim pesan. Proses melingkar ini menunjukkan bahwa komunikasi selalu berlangsung atau berproses. Pola komunikasi ini mengilustrasikan bahwa pada saat proses belajar mengajar seni musik Degung, guru dan siswa dapat berperan sebagai pengirim maupun penerima dalam sebuah interaksi. Elemen yang paling penting dalam komunikasi ini adalah adanya umpan balik (feedback) atau tanggapan terhadap suatu pesan. Umpan balik dapat berupa verbal maupun nonverbal, sengaja maupun tidak sengaja. Guru SLB Negeri Kota Depok menggunakan pola komunikasi ini untuk mengetahui apakah pesan mereka telah tersampaikan atau belum dan sejauh mana pencapaian makna terjadi setelah pesan diterima, tidak saat pesan dikirim melalui umpan balik.

Elemen terakhir dalam pola komunikasi interaksional adalah bidang pengalaman (field of experience). Pengalaman seseorang tentu berbeda-beda. Misalkan dalam proses pengajaran seni musik Degung ini, siswa berasal dari kelas satu SMA hingga kelas tiga SMA. Siswa kelas tiga SMA tentu lebih banyak pengalaman dalam memainkan Degung dibanding siswa kelas satu SMA yang baru mengenal seni musik Degung. Cara berpikir mereka juga berbeda, ada yang mudah paham dan ada yang sulit memahami ketika guru menjelaskan materi kepada mereka. Sehingga hal ini akan memengaruhi proses penerimaan pesan kepada komunikan.

Satu hal yang perlu diperhatikan oleh pengirim pesan adalah bahwa tidak semua respon penerima pesan dapat dikatakan sebagai umpan balik (feedback). Suatu respon dari penerima pesan dapat dikatakan sebagai umpan balik atau tanggapan terhadap suatu pesan jika respon tersebut mampu memengaruhi perilaku pengirim pesan selanjutnya. Misalnya guru sudah menegur murid yang bercanda, kemudian apabila murid tersebut tidak mengubah perilakunya seperti bercanda lagi, hal tersebut menunjukkan tidak terjadi umpan balik.

Selanjutnya, pola komunikasi interaksional dapat diilustrasikan bahwa seseorang dapat menjadi pengirim maupun penerima pesan dalam sebuah interaksi, tetapi tidak pada saat pesan sedang dikirim. Misalnya guru sedang memarahi muridnya terus-menerus akibat sering bercanda dengan temannya, kemudian guru tersebut "membaca" perilaku nonverbal siswanya tersebut saat dimarahi apakah ia sedih atau marah saat guru memarahi? Atau apakah siswa tersebut mendengarkan dengan baik apa yang diucapkan oleh guru? Contoh tersebut memiliki arti dalam pandangan pola komunikasi interaksional yang berasumsi bahwa dua orang berbicara dan mendengarkan, tapi tidak dalam saat yang bersamaan. (2) Pola komunikasi transaksional (transactional model of communication). Pola komunikasi transaksional ini tidak hanya melibatkan komunikasi antara guru kepada siswa saja, melainkan juga antara siswa kepada siswa. Sehingga dengan pola ini dapat membuat proses pembelajaran menjadi lebih optimal dan menumbuhkan keaktifan belajar siswa. Pola komunikasi transaksional (transactional model of communication) pada dasarnya tidak hanya melakukan komunikasi yang dinamis saja, melainkan pola komunikasi transaksional memiliki kecenderungan terhadap penilaian pribadi. Komunikasi transaksional adalah komunikasi untuk mencari makna. Sehingga komunikasi transaksional bisa memperlihatkan 
komunikasi verbal dan komunikasi nonverbal. Ini artinya setiap gerakan atau gestur tubuh juga bisa diambil sebagai suatu makna oleh orang lain. Misalnya setelah guru di SLB Negeri Kota Depok menyampaikan materi notasi Degung kemudian ditanggapi dengan anggukan kepala oleh siswa. Hal ini menunjukkan bahwa pola komunikasi transaksional telah terjadi. Anggukan kepala sebagai bentuk respon nonverbal penerima pesan akan dinilai oleh pemberi pesan berdasarkan penilaian pribadinya. Guru akan mengartikannya sebagai suatu tanda setuju. Hal tersebut merupakan penilaian dari guru terhadap respon yang diberikan oleh siswa.

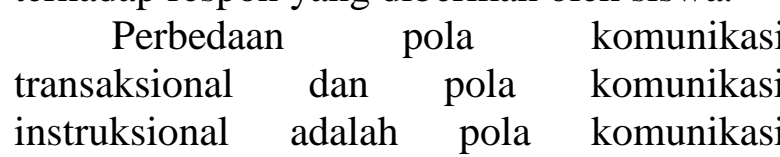
interaksional lebih mementingkan umpan balik antara guru dengan siswa dan dilakukan hanya dua arah saja. Sedangkan pola komunikasi transaksional tidak hanya dua arah tetapi banyak arah, tidak hanya guru kepada siswa tetapi bisa dari siswa kepada siswa. Misalkan guru menyampaikan materi kepada siswa, lalu guru tersebut memberikan perintah untuk bekerjasama dengan temannya sehingga guru maupun siswa mempunyai pengetahuan yang sama mengenai materinya. Hal ini yang diterapkan oleh guru dalam mengajar seni musik Degung di SLB Negeri Kota Depok. Tujuannya agar komunikasi tidak selalu hanya berasal dari guru saja yang memberikan materi, tetapi siswa diajarkan untuk bekerjasama dengan baik sekaligus melatih kemampuan berbicara dengan temannya.

Pada komunikasi transaksional ini juga terdapat bidang pengalaman, tetapi terjadi perpotongan. Dengan demikian, proses komunikasi yang berlangsung masing-masing menunjukkan proses pemahaman yang terjalin secara aktif, sehingga timbul suatu pemahaman. Misalnya guru di SLB Negeri Kota Depok menjelaskan lagi materi mengenai seperangkat alat musik Degung yang biasa disebut dengan waditra dan siswa mempraktikkan waditra tersebut. Pengalaman dalam mempelajari waditra merupakan perpotongan pengalaman di antara dua pihak yang melakukan transaksi. Kesamaan pengalaman ini membuat penyampaian materi dapat berjalan dengan baik karena siswa juga mengetahui materi mengenai waditra Degungnya. Sehingga siswa tidak mengerutkan kening saat mendengar istilahistilah waditra Degung.

Di dalam komunikasi transaksional tidak hanya sekadar pola komunikasi yang bersifat dinamis tetapi guru juga harus berupaya mengartikan makna. Sebagai contoh, ketika guru dalam menyampaikan suatu materi seni Degung kepada siswa, maka komunikasi bukan saja terjadi saat siswa menafsirkan pesan-pesan atau materi yang disampaikan oleh guru, tetapi guru juga harus menafsirkan perilaku anak didiknya seperti anak yang menggigit kuku dalam belajar, menopang kepala, berbicara dengan temannya, mengerutkan kening, dan sebagainya. Dalam proses komunikasi transaksional semuanya berlangsung secara simultan dan spontan.

Contoh lain pada saat guru menyampaikan materi seni musik Degung di kelas ada seorang siswa tidak fokus atau mengobrol dengan temannya. Melihat ada peserta didik yang mengobrol tersebut menyebabkan guru mengeraskan suara atau memberikan tekanan tertentu sehingga peserta didik tersebut menjadi diam dan kembali fokus. Dengan demikian, siswa tunagrahita atau tunarungu tersebut menyadari tindakannya dan mengubahnya menjadi fokus mendengarkan dan memperhatikan guru yang menjelaskan materi seni musik Degung sehingga guru merasa dihargai serta semakin termotivasi dalam melanjutkan pembelajaran. Maka, hal tersebut bisa dikatakan sebagai sebuah umpan balik. Termasuk di dalamnya adalah ketika seorang guru menyampaikan pembelajaran, ada peserta didik yang justru fokus pada cara guru berbicara seperti gaya dan pilihan kata guru tersebut yang menarik. Sehingga dalam konteks ini, peserta didik tidak hanya memberikan respon terhadap pelajaran yang disampaikan namun juga peserta didik secara tidak langsung memberikan respon positif terhadap gaya berbicara gurunya.

Dengan demikian, pola komunikasi yang terjadi antara guru dengan murid tunarungu dan tunagrahita tidak hanya terjadi secara satu arah, melainkan multiarah. Guru 
memberikan materi seni musik Degung, murid mengartikan pesannya dan memberikan respon sesuai kemampuan penerimaannya. Selanjutnya, guru menangkap respon yang ditunjukkan oleh murid dan memaknainya. Hasil pemaknaan ini digunakan guru untuk mempertahankan atau meningkatkan teknik pembelajaran jika respon yang diberikan oleh murid positif, dan mengubah teknik pembelajaran jika respon yang diberikan oleh murid negatif atau jelek.

\section{Hambatan dalam Proses Pembelajaran Seni Musik Degung kepada Siswa Tunarungu dan Siswa Tunagrahita di Sekolah SLB Negeri Kota Depok}

Dalam setiap belajar mengajar akan selalu ada hal-hal yang menghambat dalam proses pembelajaran. Hal tersebut tidak luput dalam proses pembelajaran seni musik Degung di SLB Negeri Kota Depok. Faktor penghambat di dalam komunikasi dibagi menjadi lima hambatan menurut West dan Turner (2008) sebagai berikut: (1) Hambatan fisik (physical barriers). Hambatan fisik didominasi oleh suasana yang ramai yang disebabkan oleh siswa-siswa yang sering bercanda atau mengajak berbicara dengan teman di sebelahnya ketika mereka sudah bosan ataupun jenuh saat latihan. Selain itu, suasana gaduh juga disebabkan oleh banyaknya orang tua yang menonton muridmurid saat belajar Degung, sehingga murid tersebut terkadang malah mengobrol dengan orang tuanya melalui jendela. Hal tersebut menyebabkan konsentrasi murid terganggu. Anak tunagrahita sering mencari perhatian apabila orang tua melihat mereka saat sedang latihan Degung, sehingga mereka memainkan alat musiknya dengan keras supaya terdengar oleh orang tuanya. Hal ini menyebabkan ketidakkompakan murid dalam memainkan Degung. (2) Hambatan semantik (semantic barriers). Hambatan semantik dalam kegiatan belajar mengajar seni musik Degung yang terjadi antara guru kepada siswa tunarungu, yaitu struktur bahasa yang digunakan tidak sebagaimana mestinya sehingga membingungkan penerima. Baik guru kepada murid maupun murid kepada guru, dengan penggunaan bahasa yang berbeda terkadang menimbulkan missed communication antara satu sama lain. Misalkan guru memberikan instruksi untuk memukul gamelan dengan notasi $d a, l a, t i, n a, m i$, da atau ayo pukul jenglong gayor, saron peking, saron cempres, dan lain sebagainya. Terkadang siswa kurang mengerti dengan istilah-istilah seperti namanama gamelan atau bonangnya dan sering lupa nama alat musiknya. (3) Hambatan psikologis (phsycological barriers). Hambatan psikologis dalam kegiatan belajar mengajar seni musik Degung di SLB Negeri Kota Depok terjadi pada siswa tunarungu dan tunagrahita. Hambatan psikologis yang dihadapi oleh siswa tunarungu disebabkan karena anak tunarungu menyadari kekurangan yang dimiliki sehingga menimbulkan rasa tidak percaya diri saat memainkan Degung. Kemudian anak tunarungu saat belajar seni musik Degung juga sering sekali mengobrol dengan temannya dikarenakan mereka tidak bisa mendengar. Sedangkan hambatan psikologis yang terjadi pada anak tunagrahita ditemukan karena emosi atau mood mereka tidak stabil. Hal ini bisa terjadi ketika dalam proses belajar di sekolah maupun saat pentas. Hal ini menjadi hambatan yang mengharuskan kegiatan belajar mengajar terhenti untuk sejenak hingga mood mereka kembali pulih. Hanya saja, ketika hambatan ini ditemukan saat latihan dengan kondisi emosi mereka sedang turun atau mood mereka tidak stabil saat berlatih seni musik, maka proses pembelajaran Degung akan berlangsung tanpa siswa tunagrahita. Misalkan mereka sedang dalam kondisi yang emosinya tinggi, apabila ditegur oleh guru karena mereka terlalu keras dalam memukul alat musiknya, terkadang marah dan tidak ingin berlatih lagi. Tetapi apabila emosinya sedang stabil, ketika ditegur justru mereka merespon dengan baik, misalkan mereka mengucapkan "oh aku salah ya", "ah aku salah nih" dan mereka melanjutkan latihan seni musik Degung-nya. (4) Hambatan fisiologis (physiological barriers). Hambatan fisiologis dalam kegiatan belajar mengajar seni musik Degung di SLB Negeri Kota Depok terjadi pada siswa tunarungu dan tunagrahita. Anak tunarungu kehilangan kemampuan dalam mendengar sehingga membuat tabuhan atau pukulan yang dihasilkan antara siswa tunarungu dan 
tunagrahita seringkali tidak selaras. Terkadang terlalu lambat atau sebaliknya, sebab anak tunarungu tidak bisa mendengar alunan musik serta simbol-simbol verbal menjadi hambatan tersendiri bagi guru. Sedangkan hambatan pada anak tunagrahita adalah intelligence quotient (IQ) anak tunagrahita di bawah rata-rata dan sulit mengingat. Sehingga siswa tunagrahita mudah lupa dengan apa yang diajarkan oleh guru. Apalagi ketika mendapatkan partitur musik baru, guru harus mengulang-ulang setiap materi sesering mungkin karena mereka sulit menghafal. Selain itu siswa tunagrahita melakukan gerakan memukul alat musiknya secara tidak dinamis. Kemudian anak tunagrahita memiliki karakteristik sulit dalam menangkap pelajaran dan sulit memusatkan perhatiannya sehingga kurang fokus dalam berlatih. Apabila mereka merasa tidak bisa memainkan alat musiknya, mereka akan berhenti bermain dan justru akan mengganggu temannya.

\section{PENUTUP}

\section{Simpulan}

Di SLB Negeri Kota Depok, guru dalam menyampaikan pesan berupa materi seni musik Degung menggunakan komunikasi verbal dan nonverbal. Bentuk komunikasi verbal yang dilakukan oleh guru seni musik Degung kepada siswa tunarungu menggunakan bahasa lisan dengan pengucapan secara perlahan dan penggunaan kata-kata yang sederhana sehingga mereka bisa membaca gerak bibir guru. Sedangkan komunikasi yang dilakukan guru kepada siswa tunarungu menggunakan komunikasi nonverbal berupa gerakan tubuh, meliputi emblem, illustrator, effect display, regulator, dan adaptor.

Pola komunikasi yang digunakan guru dalam proses pengajaran seni musik Degung di SLB Negeri Kota Depok menggunakan dua pola komunikasi, yaitu pola komunikasi interaksional yang lebih menekankan adanya umpan balik dan pola komunikasi transaksional yang menekankan adanya pemaknaan makna.
Terdapat hambatan yang terjadi dalam menyampaikan materi seni musik Degung kepada siswa berkebutuhan khusus. Pertama, hambatan fisik (physical barriers) yang disebabkan oleh suasana kelas yang ramai akibat siswa-siswa banyak mengobrol. Suasana ini juga seringkali disebabkan karena orang tua sering melihat melalui jendela sehingga siswa tersebut tidak konsentrasi. Kedua, hambatan semantik (semantic barriers) yang terjadi antara guru kepada siswa tunarungu, yaitu struktur bahasa yang digunakan tidak sebagaimana mestinya, sehingga membingungkan, baik guru kepada murid maupun murid kepada guru. Penggunaan bahasa yang berbeda terkadang menimbulkan missed communication antara satu sama lain, baik ketika guru sedang memberikan instruksi maupun saat murid menanyakan sesuatu hal mengenai Degung kepada guru.

Hambatan ketiga yaitu hambatan psikologis (phsycological barriers) yang muncul ketika anak tunarungu menyadari kekurangan yang dimiliki sehingga menimbulkan rasa tidak percaya diri saat memainkan Degung. Sedangkan hambatan psikologis yang terjadi pada anak tunagrahita ditemukan karena emosi atau mood mereka tidak stabil. Hambatan keempat adalah hambatan fisiologis (physiological barriers) yang terlihat saat guru menjelaskan materi, terkadang anak tunagrahita saling berteriakteriak dengan temannya, begitu juga anak tunarungu. Teriakan-teriakan ini merupakan bentuk hambatan fisiologis yang dapat menghambat isi pesan yang dikomunikasikan.

\section{Saran}

Dalam proses kegiatan belajar mengajar kesenian musik tradisional Degung di SLB Negeri Kota Depok sudah baik. Hanya saja guru menghadapi kendala dari faktor fisik sehingga tidak bisa menangani atau mengontrol siswa tunagrahita yang hiperaktif sehingga dibutuhkan sumber daya guru yang muda untuk membantu proses pengajaran seni musik Degung demi efektivitas komunikasi antara guru dengan murid. Sehingga setiap karakteristik anak dapat ditangani oleh guru dengan baik. 


\section{DAFTAR PUSTAKA}

Ali, M. (2007) Ilmu \& Aplikasi Pendidikan. Bandung, PT IMTIMA.

Baqiroh, N.F.A.B. (2018) Mendikbud akan Bentuk Direktorat Khusus Disabilitas.

Devito, J.A. (2011) Komunikasi Antar Manusia. 5th edition. Tangerang, Karisma Publishing Group.

Effendi, M. (2009) Pengantar Psikopedagogig Anak Berkelainan. Jakarta, Bumi Aksara.

Effendy, O.U. (2011) Ilmu Komunikasi Teori dan Praktek. Bandung, Remaja Rosdakarya.

Fiske, J. (2012) Pengantar Ilmu Komunikasi. Jakarta, PT Raja Grafindo Persada.

Hijrah (2017) Hambatan Komunikasi Interpersonal Kaum Lesbian Virginity dalam Pergaulan Sehari-hari di Kota Palu. Jurnal Online Kinesik. 4 (2), 45-56.

Julia, Supriyadi, Tedi, dan P.D.I. (2018) Improving Prospective Primary School Teachers' Skill in Playing Gamelan Degung: An Action research in Indonesia. Journal of Arts Research and Education. 18 (2), 117-130.

Kusnarto dan Saifudin Z (2010) Pola Komunikasi Suami Istri yang Menjadi Tenaga Pembantu Rumah Tangga di Hari Lebaran. Jurnal Ilmu Komunikasi. 2 (1), 1-9.

Kustawan, D. (2016) Bimbingan an Konseling bagi Anak Berkebutuhan Khusus. Jakarta Timur, PT. Luxima Metro Media.

Kusumawati, T.I. (2016) Komunikasi Verbal dan Nonverbal. Jurnal Al-Irsyad. VI (2).

Lestari, Maya Puji, Naryoso, Agus, dan W.N.R. (2013) Memahami Pengalaman Komunikasi Antar Pribadi Orang Tua, Guru, dengan Anak Tunawicara dalam Menanamkan Nilai Prososial dan Antisosial di Masyarakat. Interaksi Sosial. 1 (3), 1-13.

Majid, A. (2013) Strategi Pembelajaran. Bandung, PR Remaja Rosdakarya.

Maulipaksi, D. (2017) Sekolah Inklusi dan Pembangunan SLB Dukung Pendidikan Inklusi. [Online]. 2017. Available from: https://www.kemdikbud.go.id/main/blog/20 17/02/sekolah-inklusi-dan-pembangunanslb-dukung-pendidikan-inklusi.

Mudjito (2013) Mengembangkan Bakat-bakat Istimewa Anak Berkebutuhan Khusus. 2013.

Mulyana, D. (2012) Ilmu Komunikasi Suatu Pengantar. Bandung, Remaja Rosdakarya.

Mulyana, D. (2010) Ilmu Komunikasi Suatu Pengantar. Bandung, Remaja Rosdakarya.

Mulyana, D. (2005) Pengantar Ilmu Komunikasi. Bandung, Remaja Rosdakarya.

Nurmala, Rina, Syarif Maulana, dan A.P. (2016) Komunikasi Verbal dan Nonverbal dalam Proses Kegiatan Belajar Mengajar. eproceeding of Management. 3 (1).

Putri, W.D. (2015) Terapi Musik pada Anak Berkebutuhan Khusus, dapat Melatih Sistem Motorik. [Online]. 2015. Available from:

https://www.republika.co.id/berita/gayahidup/parenting/15/02/07/njdrbg-terapimusik-pada-anak-berkebutuhan-khususdapat-melatih-sistem-motorik Diakses pada [Accessed: 7 October 2015].

Resna, R.W., Yusniarsih, I., dan Yuliani, P.L. (2017) Study on Gamelan Degung as Music Therapy in an Active Labor Phase on the First Stage of Labor by Using Pain Intensity Rating Scale. International Journal of Advances in Science Engineering and Technology. 5 (3), 87-89.

Sari, Siti Fatimah Mutia, Binahayati, dan B.M. (2017) Pendidikan Bagi Anak Tuna Grahita: Studi Kasus Tunagrahita Sedang di SLB N Purwakarta. Jurnal Penelitian dan PKM. 4 (2), 217-222.

Sugiyono (2016) Metode Penelitian Kuantitatif dan RND. Bandung, Alfabeta.

Wasito, Dian rachmawati, Dwi Sarwindah, dan W.S. (2010) Penyesuaian Sosial Remaja Tuna Rungu yang Bersekolah di Sekolah Umum. Jurnal INSAN. 12 (3).

West, R. \& Turner, L.H. (2008) Pengantar Teori Komunikasi: Analisis dan Aplikasi. 3rd edition. Nana Setyaningsih (ed.). Jakarta, Salemba Humanika. 